\title{
SPREMNOST ZA OVLADAVANJE VJEŠTINAMA ČITANJA \\ I PISANJA NA HRVATSKOME JEZIKU KOD DJECE ROMSKE NACIONALNE MANJINE - JEDNAK POČETAK
}

\author{
ZA SVE?
}

\section{READINESS OF ROMA CHILDREN FOR READING AND WRITING ACQUISITION IN THE CROATIAN LANGUAGE - AN EQUAL STARTING POINT FOR ALL?}

\author{
VALENTINA MARTAN ${ }^{1}$, IVANA SREBAČIĆ \\ ${ }^{1}$ Studij Logopedija, Sveučilište u Rijeci, Rijeka, Hrvatska, Hrvatska, kontakt: vmartan@uniri.hr \\ ${ }^{2}$ Osnovna škola Kuršanec, Čakovec, Hrvatska
}

Primljeno/Received: 08.07.2020.

Prihvaćeno/Accepted: 10.11.2020.
Izvorni znanstveni $\mathrm{rad} /$ Original research article UDK: $376-054.57(=214.58): 81^{`} 232$

$376-054.57(=214.58): 81^{`} 4$

doi: 10.31299/hrri.56.2.5
Sažetak: U Republici Hrvatskoj živi više od 16 tisuća pripadnika romske nacionalne manjine. Budući da nemaju standardiziran vlastiti jezik i pismo, djeca Romi ${ }^{l}$ školuju se po redovnom planu i programu na hrvatskome jeziku. To podrazumijeva i usvojenost predvještina čitanja i pisanja prije polaska u prvi razred. Cilj je ovoga rada ispitati razinu usvojenosti predvještina čitanja i pisanja kod djece Roma te utvrditi razlikuju li se djeca Romi $(N=56,62,5 \%$ dječaka, $M=6$ god., 8 mj., $S D=0,46)$ i djeca čiji je materinski jezik hrvatski $(N=55,50,9 \%$ dječaka; $M=6$ god., 8 mj., $S D=0,4)$ u razvijenosti pojedinih sastavnica predvještina čitanja $i$ pisanja. Ispitivanje je provedeno odabranim zadacima iz Testa za procjenu predvještina čitanja i pisanja (PredČip test, Kuvač Kraljević i Lenček, 2012). Rezultati su očekivani i ukazuju na to da djeca Romi na većini ispitanih varijabli odstupaju od urednoga postignuća. U odnosu na kontrolnu skupinu sudionika istraživanja djeca Romi pokazuju statistički značajno niže rezultate na gotovo svim testiranim varijablama (izuzev mjera slogovnog i fonemskog stapanja). Dobiveni rezultati pokazatelj su nedovoljne usvojenosti pojedinih sastavnica predvještina čitanja i pisanja na hrvatskome jeziku te nedostatno razvijenih vizualno-perceptivnih sposobnosti.

1 Termin “djeca Romi” odnosi se na djecu pripadnike romske nacionalne manjine./ The term "Roma children" refers to children belonging to the Roma national minority.

\begin{abstract}
Over 16,000 people belong to the Roma national minority in the Republic of Croatia. Given the fact that they do not have their own standardised language and orthography, Roma children ${ }^{l}$ attend regular schools and regular curriculum in the Croatian language. This also implies the acquisition of reading and writing prerequisites prior to enrolment into first grade. The aim of this paper is to examine the level of acquisition of reading and writing prerequisites in Roma children and to determine whether Roma children $(N=56$, $62.5 \%$ of boys, $M=6$ years, 8 months, $S D=0.46$ ) differ from children whose first language is Croatian $(N=55,50.9 \%$ of boys; $M=6$ years, 8 months, $S D=0.4$ ) in the development of individual components of reading and writing prerequisites. Testing was performed through selected tasks from the Test for the assessment of reading and writing prerequisites (PredČip test, Kuvač Kraljević \& Lenček, 2012). The results were as expected and indicate that Roma children deviate from regular achievement on most of the examined variables. In comparison to the control group of participants, Roma children demonstrated significantly lower results on almost all tested variables, apart from syllable and phonemic blending. The obtained results are an indicator of insufficient acquisition of certain components of reading and writing prerequisites in the Croatian language and insufficiently developed visualperceptual abilities. Considering that reading and writing prerequisites are the important precondition for fluent reading
\end{abstract}


Budući da su predvještine čitanja i pisanja važan preduvjet za usvajanje tečnoga čitanja i pisanja, kao i akademskih postignuća, vidljivo je da djeca Romi nisu spremna za školu $i$ već u samome početku ne mogu održati korak sa svojim vršnjacima. Samim time potrebno je sustavno mijenjati sustav predškolskoga i školskoga odgoja i obrazovanja kada je u pitanju ova posebno ranjiva skupina djece.

Ključne riječi: predvještine čitanja i pisanja, Romi, školski obveznici, spremnost za školu

\section{UVOD}

Romska nacionalna manjina jedna je od 22 nacionalne manjine u Republici Hrvatskoj. Pripadnici romske nacionalne manjine materinski su govornici triju različitih jezika (bajaški rumunjski, romani ćhiba i albanski), za koje najčešće imaju univerzalni naziv - romski jezik (Radosavljević, 2016). U Međimurskoj županiji Romi su govornici bajaškoga rumunjskog, čija je karakteristika da ima mnogo posuđenica iz hrvatskoga jezika (Radosavljević, 2016). Razvio se iz arhaičnoga rumunjskog te se s vremenom promijenio i jezično interferirao s hrvatskim, ali nikada nije razvio pisani oblik (Radosavljević, 2009). Djeci romske nacionalne manjine hrvatski je drugi jezik. Drugi je jezik većinski jezik okoline u kojoj pojedinac živi i djeluje (Jelaska, 2007a) te se najčešće definira kao onaj "jezik koji pojedinac usvaja nakon što je već usvojio jedan jezik" (Jelaska i sur., 2005: 27).

U Međimurskoj županiji Romi najčešće žive u segregiranim naseljima u kojima izostaje svakodnevna komunikacija s izvornim govornicima hrvatskoga jezika (Dobravac, Cvikić i Kuvač Kraljević, 2011). Zbog života u prostorno segregiranim uvjetima djeca Romi najčešće ne usvajaju hrvatski jezik sve do polaska u predškolu (Turza-Bogdan i Cvikić, 2020). Većina djece Roma u Međimurskoj županiji polazi desetomjesečni program predškole.

U Republici Hrvatskoj pripadnici manjina mogu se školovati prema trima modelima: (1) model A predviđa provođenje cjelokupne nastave na jeziku i pismu nacionalne manjine, uz obavezno učenje hrvatskoga jezika u istom broju sati u kojemu se uči jezik manjine, (2) model B predviđa dvojezično izvođenje nastave u kojemu se prirodna grupa predmeta uči na hrvatskome, a društvena na jeziku and writing, it is clear that Roma children are not prepared for school education and that they demonstrate difficulties in keeping up with their peers at the beginning of formal school education. This implies the need for a systematic change of the preschool and school system with regards to this especially vulnerable group of children.

Key words: reading and writing prerequisites, Roma people, preschool children, readiness for school

\section{INTRODUCTION}

The Roma national minority is one of 22 national minorities in the Republic of Croatia. Members of the Roma national minority speak three different languages (Bayash Romanian, Romani Ćhib and Albanian) for which they have one universal name - Romani language (Radoslavljević, 2016). In Međimurje County, Roma people speak Baja Romanian, which features many loanwords from the Croatian language (Radosavljević 2016). It developed from the archaic Romanian, changed over time and linguistically interfered with Croatian, but never developed a written form (Radosavljević, 2009). For Roma children, Croatian is a second language. A second language is the majority language of the environment in which the individual lives and works (Jelaska, 2007a), most often defined as "the language that an individual acquires after having already acquired one language" (Jelaska et al., 2005: 27).

In Međimurje County, Roma people most often live in segregated settlements in which there is a lack of everyday communication with native speakers of the Croatian language (Dobravac, Cvikić \& Kuvač Kraljević, 2011). Since they live in spatially segregated conditions, Roma children usually do not learn the Croatian language until they start attending preschool (Turza-Bogdan \& Cvikić, 2020). In the year before the beginning of formal education, most Roma children in Međimurje County attend a 10-month preschool programme.

Members of minorities in the Republic of Croatia can attend school education according to three models: (1) model A refers to school education in language and orthography of the national minority, with obligatory Croatian language learning at the same frequency at which the minority language is taught; 
nacionalne manjine, dok se prema (3) modelu C nastava provodi na hrvatskome jeziku uz dodatnih dva do pet školskih sati posvećenih njegovanju jezika i kulture nacionalne manjine. Učenici Romi školuju se prema modelu C. Oni se prilikom polaska u školu uključuju u dopunsko učenje hrvatskoga jezika u trajanju od 70 sati nastave godišnje (Pravilnik o provođenju pripremne $i$ dopunske nastave za učenike koji ne znaju ili nedostatno znaju hrvatski jezik i nastave materinskoga jezika i kulture države podrijetla učenika, NN 15/13).

Osim nejednakosti u početnoj jezičnoj poziciji, pri čemu se pri polasku u školu djeca Romi izjednačavaju s izvornim govornicima hrvatskoga jezika, dodatna je otegotna okolnost činjenica da najčešće žive u neadekvatnim socioekonomskim uvjetima, uz nedovoljno obrazovane roditelje i nedovoljno kognitivno stimulirajuće kućno okruženje (Biro, Smederevac i Tovilović, 2009). Većina djece Roma živi u relativnom siromaštvu, pri čemu ih čak $9 \%$ živi u apsolutnom siromaštvu (Bagić, Burić, Dobrotić, Potočnik i Zrinščak, 2014). Siromaštvo među Romima raširenije je nego u općoj populaciji te je znatno dublje i trajnije (Kutnjak Vrtarić, 2017). Tradicionalne vrijednosti nerijetko prostorno segregiranih romskih zajednica uključuju rano stupanje u brak, rano zaposlenje i obitelji s mnogo djece te su prepreka njihovu dugoročnijem i kvalitetnom obrazovanju (Pahić, Vizek Vidović i Miljević-Riđički, 2011). S obzirom na to da im je materinski jezik bajaški, očekivani su rezultati istraživanja koji pokazuju da samo $6 \%$ Roma govori hrvatskim jezikom u kućnome okruženju (Pahić i sur., 2011), dok je stopa nepismenosti u romskoj populaciji $15 \%$ (Bagić i sur., 2014).

Budući da djeca Romi do polaska u školu najčešće ne usvajaju hrvatski jezik na razini materinskoga bajaškog, već su time u lošijoj početnoj poziciji na početku osnovnoškolskoga obrazovanja, što želimo pokazati i istraživanjem prikazanim u ovome radu. Jedan od važnih pokazatelja spremnosti djeteta za početak formalnoga obrazovanja jest usvojenost predvještina čitanja i pisanja prije polaska u prvi razred. Naime ulaskom u obrazovni sustav od djece se očekuje određeni stupanj spremnosti koji uključuje usvojenost predvještina čitanja i pisanja kako bi lakše usvojili znanja i vještine koje se od njih očekuju u osnovnoj školi. Stoga
(2) model B refers to bilingual classes in which science subjects are taught in Croatian and social subjects in the minority language; while (3) model $\mathrm{C}$ classes are taught in Croatian, with another 2-5 school classes dedicated to fostering language and culture of the national minority. Roma students are educated according to model C. Upon entering formal education, they attend additional classes of Croatian in the form of 70 classes per year (Regulation on implementing preparatory and supplementary classes for students who do not know the Croatian language, and on teaching language and culture of students' country of origin, Official Gazette 15/13).

Apart from inequalities in the initial language position, where Roma children are equated with native speakers of the Croatian language when starting school, an additional aggravating circumstance is the fact that most live in poor socioeconomic conditions with inadequately educated parents and a household environment that is inadequately cognitively stimulated (Biro, Smederevac \& Tovilović, 2009). Most Roma children live in relative poverty, and up to $9 \%$ of them live in absolute poverty (Bagić, Burić, Dobrotić, Potočnik \& Zrinščak, 2014). Poverty among Roma people is more widespread than in the general population and is far deeper and long-lasting (Kutnjak Vrtarić, 2017). Traditional values of often spatially segregated Roma communities include early marriage, early employment and families with many children, which present a barrier to the length and quality of their education (Pahić, Vizek Vidović \& Miljević-Riđički, 2011). Since their mother tongue is Bajic, the results of research that show that only $6 \%$ of Roma people speak Croatian in their households are expected (Pahić et al., 2011), while the percentage of illiteracy in the Roma population is $15 \%$ (Bagić et al., 2014).

Since Roma children usually do not acquire Croatian language at the level of native speakers until they start school, they are in a worse starting position at the beginning of primary education, which we want to show through the research presented in this paper. One of the important indicators of a child's readiness to start formal education is acquisition of reading and writing prerequisites before starting first grade. By entering the school system, Roma children are expected to have a certain degree of readiness, which includes the acquisition of reading and writing 
ćemo u sljedećemu poglavlju pobliže objasniti što sve te predvještine uključuju.

\section{PREDVJEŠTINE ČITANJA I PISANJA}

Predvještine čitanja i pisanja predstavljaju niz temeljnih sposobnosti i vještina koje su preduvjet tečnomu čitanju i pisanju (Scarborough, 2001). Brojna istraživanja bave se jasnim određivanjem vještina i procesa koji prethode uspješnomu ovladavanju predvještinama čitanja i pisanja, njihovim obilježjima, povezanošću, kao i prediktivnošću za uspješno ovladavanje čitanjem i pisanjem (npr. Blaži, Buzdum i Kozarić-Cviković, 2011; Hogan, Catts i Little, 2005; Kuvač Kraljević, Lenček i Matešić, 2019).

Predvještine čitanja i pisanja ne podučavaju se formalno i razvijaju se u prvih pet godina života, a sastoje se od fonološke svjesnosti, poznavanja rječnika, pripovjedne sposobnosti, interesa za tisak i koncept tiska, imenovanja slova i fonološkoga radnog pamćenja (Ivšac Pavliša i Lenček, 2011; Kuvač Kraljević i Lenček, 2012). Fonološki procesi jezična su znanja i vještine čija se važnost najčešće spominje u kontekstu razvoja vještina čitanja i pisanja (Ramus, 2003). Fonološka svjesnost sposobnost je promišljanja o izgovorenoj riječi u odnosu na fonološke jedinice - slog, rimu i fonem (Ouellette i Haley, 2011), koja se javlja u predškolskome i ranijemu školskom razdoblju, a manifestira se kroz sposobnosti prepoznavanja, razlikovanja i manipulacije glasovima jezika (Anthony i Francis, 2005). Dijeli se na implicitnu i eksplicitnu razinu pri čemu se implicitna razina odnosi na razinu riječi i sloga, a eksplicitna razina na fonemsku razinu, odnosno te se razine mogu podijeliti s obzirom na načelo uporabe na vještine raščlambe i stapanja (Ouellette i Haley, 2011). Mjeru fonološke obrade čini i sposobnost raščlambe rečenica na riječi, koja uključuje eksplicitno jezično znanje (Kuvač Kraljević i Lenček, 2012). Imenovanje slova također je važan pretkazatelj uspjeha u čitanju, osobito u alfabetskim jezicima s transparentnom ortografijom (Anthony i Francis, 2005), a budući uspjeh u prepoznavanju riječi i čitanju snažno predviđa i brzo imenovanje poznatih predmeta (Caravolas i Landerl, 2010; Manis, Lindsey i Bailey, 2004; Norton i Wolf, 2012). Fonološko pamćenje, kao mjera fonološke obrade, uključuje kodiranje i uskladištavanje najmanjih prerequisites to make it easier for them to acquire expected knowledge and skills in primary school. Therefore, in the next section, we will explain in more detail what the prerequisites include.

\section{READING AND WRITING PREREQUISITES}

Reading and writing prerequisites represent a series of fundamental abilities and skills that are a prerequisite for fluent reading and writing (Scarborough, 2001). Numerous studies deal with the clear determination of skills and processes preceding successful mastering of reading and writing prerequisites, their characteristics, connection and prediction for successful reading and writing acquisition (e.g., Blaži, Buzdum \& KozarićCviković, 2011; Hogan, Catts \& Little, 2005; Kuvač Kraljević, Lenček \& Matešić, 2019).

Reading and writing prerequisites are not taught formatively and are developed in the first five years of life. They consist of phonological awareness, vocabulary knowledge, narrative ability, interest for print and the concept of print, naming letters and phonological working memory (Ivšac Pavliša \& Lenček, 2011; Kuvač Kraljević \& Lenček, 2012). Phonological processes include language knowledge and skills, the importance of which is most commonly mentioned in the context of the development of reading and writing skills (Ramus, 2003). Phonological awareness is the ability to think about the spoken word in relation to phonological units - syllable, rhyme and phoneme (Ouellette \& Haley, 2011). This unique ability occurs in preschool and the early school period and is manifested through the abilities of recognition, distinction and manipulation with sounds of language (Anthony $\&$ Francis, 2005). It is divided into implicit and explicit levels, whereby implicit refers to word and syllable levels, while explicit refers to a phoneme level, i.e. these levels can be divided based on the principle of segmentation and blending (Ouellette \& Haley, 2011). Phonological processing measures include the ability to divide sentences into words, which includes explicit language knowledge (Kuvač Kraljević \& Lenček 2012). Naming letters is also an important indicator of success in reading, especially in alphabetic languages with transparent orthographies (Anthony \& Francis, 2005). Future success in word recognition and reading can be predicted through rapid naming of familiar objects (Caravolas \& Landerl, 2010; Manis, Lindsey 
jezičnih jedinica kako bi se njima moglo brzo i točno pristupati, zadržavati ih, obrađivati i njima baratati (Kelić, Zelenika Zeba i Kuvač Kraljević, 2016). Navedene vještine također utječu na proces usvajanja čitanja i pisanja (Gathercole, Alloway, Willis i Adams, 2006; Kibby, Marks, Morgan i Long, 2004), a najčešće se ispituju kroz ponavljanje riječi, pseudoriječi ili rečenica (Kuvač Kraljević i Lenček, 2012). Uz jezična znanja i sposobnosti u kontekstu rane pismenosti važne su i druge vještine poput vizualne percepcije, grafomotorike i pažnje, kao i okolinski čimbenici, među kojima je najznačajnije kućno okruženje (Kuvač Kraljević i sur., 2019). Poznato je da je obiteljski kontekst najutjecajniji okolinski čimbenik koji utječe na kognitivni razvoj djece u najranijemu razdoblju njihova života (Biro i sur., 2009), a rano poticanje pismenosti u kućnome okruženju utječe na spremnost za usvajanje čitanja i pisanja i na drugome jeziku (Kyuchukov, 2006). Osim roditeljske brige i poticanja važan prediktor ranih jezičnih vještina, socijalnih kompetencija i uspjeha u školi jest socioekonomski status (McLoyd, 1998). Roditelji i skrbnici nižega socioekonomskog statusa nedovoljno čitaju s djecom (Bracken i Fischel, 2008) te samim time i manje potiču razvoj predvještina čitanja i pisanja.

\section{RAZVOJ (PRED)VJEŠTINA ČITANJA I PISANJA NA DRUGOME JEZIKU}

Usvajanje pismenosti na prvome, kao i na drugome jeziku sustavni je proces koji se uči te ima svoje specifične faze, mehanizme i pravila, a značajno utječe na kvalitetu života u suvremenome društvu (Zorman, 2010). Uzimajući u obzir sociokulturne razlike i kasnije usvajanje drugoga jezika, za djecu koja nisu izvorni govornici jezika na kojemu se vrši poduka proces usvajanja pismenosti puno je izazovniji (Lesaux, Geva, Koda, Siegel i Shanahan, 2008). Stoga je određivanje prediktora procesa razvoja pismenosti na drugome jeziku složen proces koji se ne može univerzalno odrediti. Među brojnim čimbenicima koji utječu na taj proces primarno se ističe poznavanje drugoga jezika na razini recepcije i ekspresije, interferencije prvoga jezika te međujezične razlike na razini fonologije, ortografije, morfologije i sintakse (Erdos, Genesee, Savage i Haigh, 2010; Lesaux i sur., 2008; Verhoeven, 2000). Chan i Sylva (2015) također govore o ključnim vještinama koje imaju
\& Bailey, 2004). Phonological memory as a phonological processing measure includes coding and storing smallest units of language to access, keep, process and use them quickly and correctly (Kelić, Zelenika Zeba \& Kuvač Kraljević, 2016). Mentioned skills also influence the acquisition process (Gathercole, Alloway, Willis i Adams, 2006; Kibby, Marks, Morgan i Long, 2004) and are most frequently assessed through tasks of word, pseudoword or sentence repetition (Kuvač Kraljević \& Lenček, 2012). Along with language knowledge and abilities in the context of early literacy, other skills such as visual perception, graphomotoric skills and attention are also important, as well as environmental factors, with the household environment being the most significant one. It is well known that the family context is the most influential environmental factor influencing the cognitive development of children in the earliest period of their lives (Biro et al., 2009), and early encouragement of literacy in the home environment affects the readiness to learn to read and write in a second language (Kyuchukov, 2006). In addition to parental care and encouragement, an important predictor of early language skills, social competencies, and school success is socioeconomic status (McLoyd, 1998). Parents of lower socioeconomic status do not read enough with their children (Bracken \& Fischel, 2008), and thus they encourage less the development of reading and writing prerequisites.

\section{DEVELOPMENT OF (PRE)READING AND WRITING SKILLS IN A SECOND LANGUAGE}

Acquisition of literacy in the first as well as in the second language is a systematic process that is learned and has its own specific phases, mechanisms and rules, and significantly affects the quality of life in modern society (Zorman, 2010). Taking into account sociocultural differences and later second language acquisition, the literacy acquisition process is much more challenging for children who are not native speakers of the language of instruction (Lesaux, Geva, Koda, Siegel \& Shanahan, 2008). Therefore, determining the predictors of the process of literacy development in another language is an equally complex process that cannot be universally determined. Among the many factors influencing this process, the most important are knowledge of the second language at the level of 
visoku razinu prediktivnosti uspjeha u čitanju i pisanju na prvome i na drugome jeziku, a to su: govorni jezik, vještine fonološke obrade i svjesnost o konceptu tiska. Zbog otežane jezične kontrole usvajanje čitanja na drugome jeziku mnogoj djeci može predstavljati izazov (Grabe, 2010).

Usprkos generalno identificiranim specifičnostima obrasce usvajanja (pred)vještina čitanja i pisanja na drugome jeziku opravdano je promatrati jedino kroz prizmu ciljane manjinske populacije (Oller i Jarmulowicz, 2007). U Republici Hrvatskoj niz se istraživanja bavio procesima usvajanja hrvatskoga jezika kod romske nacionalne manjine (npr. Cvikić i Jelaska, 2005; TurzaBogdan i Ciglar, 2011). Poznato je da djeca Romi ne vladaju hrvatskim jezikom na razini vršnjaka izvornih govornika, a zaostajanje u stjecanju njihovih jezičnih kompetencija na hrvatskome jeziku uvjetovano je međusobno povezanim jezičnim i nejezičnim čimbenicima (Cvikić i Kuvač, 2007; Turza-Bogdan i Ciglar, 2011). Hrvatić (2005) navodi da tek u prvih nekoliko godina formalnoga obrazovanja djeca Romi dosegnu receptivni stupanj bilingvizma, dok tek dio njih na kraju četvrtoga razreda dosegne reproduktivni stupanj koji se manifestira u izražavanju mišljenja na drugome jeziku, upotrebi većega broja riječi i gramatičkih pravila i mogućnosti ponavljanja složenijih sintaktičkih oblika. Cvikić i Kuvač (2007) govore da je rječnik školskih obveznika Roma sužen, morfološka sastavnica jezika usvojena je na vrlo niskoj razini, glagolski vid specifičan za hrvatski jezik nije usvojen, a opće jezične i komunikacijske sposobnosti na hrvatskome jeziku nedovoljne su za samostalno slaganje rečenica i većih jezičnih cjelina. Osim toga zbog nedovoljnih kontakata s vlastitim jezikom i kulturom njihova je razina usvajanja bajaškoga rumunjskog također na niskoj razini (Turza-Bogdan, Cvikić i Svetec, 2007).

Dosadašnja su istraživanja o uspjehu djece Roma na zadacima predvještina čitanja i pisanja nedostatna. Pojedina, rijetka istraživanja, ukazuju na to da djeca iz manjinskih skupina, uključujući i djecu Rome, pokazuju slabije rezultate na mjerama fonološke svjesnosti, brzoga imenovanja te fonološkoga imenovanja u odnosu na djecu pripadnike većinskoga stanovništva (López-Escribano i Beltrán, 2009). Međutim mora se napomenuti da reception and expression, first language interference and interlingual differences at the level of phonology, orthography, morphology and syntax (Erdos, Genesee, Savage \& Haigh, 2010; Lesaux et al., 208; Verhoeven, 2000). Chan and Sylva (2015) also talk about key skills that have a high level of predictiveness about the success in reading and writing in the first as well as the second language, i.e. spoken language, phonological processing skills and awareness of the concept of the print. Due to difficult language control, learning to read in another language can be challenging for many children (Grabe, 2010).

Despite the generally identified specifics, patterns of acquisition of (pre)reading and writing skills in a second language can be observed only through the prism of the target minority population (Oller \& Jarmulowicz, 2007). In the Republic of Croatia, a number of studies have addressed the processes of Croatian language acquisition among the Roma national minority (eg., Cvikić \& Jelaska, 2005; Turza-Bogdan \& Ciglar, 2011). It is well known that Roma children do not speak Croatian at the level of native speakers, and the lag in mastering their language competencies in Croatian is caused by interrelated linguistic and non-linguistic factors (Cvikić \& Kuvač, 2007; Turza-Bogdan \& Ciglar, 2011). Hrvatić (2005) states that only in the first few years of formal education Roma children reach the receptive level of bilingualism, while only some of them reach the reproductive level at the end of the fourth grade, which is manifested in expressing thoughts in another language, using more words and grammar rules and repeating more complex syntactic forms. Cvikić and Kuvač (2007) say that the vocabulary of Roma school children is narrowed, the morphological component of the language is adopted at a very low level, the verb forms specific to the Croatian language are not adopted and general language and communication skills in the Croatian language are insufficient for independent composition of sentences and larger linguistic units. In addition, their level of acquisition of Baja Romanian is also low due to insufficient contacts with their own language and culture (Turza Bogdan, Cvikić \& Svetec, 2007).

Studies conducted so far on the success of the Roma national minority on tasks regarding reading and writing prerequisites are insufficient. Rare studies imply that children from minority groups, 
je istraživanje López-Escribana i Beltrána (2009) provođeno s Romima koji su izvorni govornici španjolskoga, što je bitno različito od situacije u Hrvatskoj gdje Romi nisu izvorni govornici hrvatskoga. Romska djeca u usporedbi s kontrolnom skupinom ispitanika postižu niže rezultate na zadacima fonološke svjesnosti koji se prolongiraju i u razdoblje prvoga razreda (Dolean, Tincas i Damsa, 2016).

Zbog nedovoljna poznavanja hrvatskoga jezika djeca Romi očekivano postižu slabije rezultate na različitim jezičnim zadacima (Cvikić i Kuvač, 2007), koji uključuju i fonološke vještine ključne za usvajanje čitanja i pisanja. U nacionalnome istraživačkom prostoru istraživanje usvojenosti predvještina čitanja i pisanja kod djece Roma jedina je provela Kovačić (2013). Na malome uzorku romskih sudionika i kontrolne skupine dobiveni rezultati potvrđuju tezu da djeca Romi postižu slabije rezultate na testovima izrađenima primarno za hrvatski jezik te su nespremna za polazak u prvi razred. Godine 2011. Radna skupina za praćenje i nadzor realizacije posebnog programa za učenje hrvatskog jezika za učenike pripadnike romske nacionalne manjine koja je imenovana u svrhu izvršenja presude Europskoga suda za ljudska prava u predmetu Oršuš i drugi protiv Hrvatske $e^{2}$ analizirala je što učitelji prepoznaju kao najveće teškoće u svladavanju hrvatskog jezika, čitanja i pisanja. Među ostalim ističu da romski učenici i u višim razredima osnovne škole nemaju usvojenu fonemsku svjesnost i još uvijek ne imenuju sva slova pravilno.

Od učenika Roma očekuje se da će s približno jednakim sposobnostima ući u školski sustav te da će biti u mogućnosti pratiti redovni kurikulum uz minimalne individualne prilagodbe. Ova skupina učenika pokušava "uhvatiti korak" s vršnjacima već na samome početku formalnoga obrazovanja (Baucal, 2006), a u radu s njima uočavaju se teškoće već u ranome praćenju nastavnoga plana i programa. Budući da djeca Romi dolaze iz okoline koja je jezično i kulturno različita, a vrlo često i socioekonomski ograničavajuća, nameće se potreba podrobnije analize različitih aspekata njihove spremnosti za ulazak $u$ formalni sustav odgoja i

2 Predmet je dostupan na poveznici - https://www.refworld.org/ pdfid/4ba208fc2.pdf / The subject is available at the link - https:// www.refworld.org/pdfid/4ba208fc2.pdf including Roma children, demonstrate lower results in phonological awareness, rapid naming and phonological naming measures in comparison to children belonging to the majority population (LópezEscribano \& Beltrán, 2009). However, it should be noted that the research of López-Escriban and Beltrán (2009) was conducted on Roma people who are native speakers of Spanish, which is significantly different from the situation in Croatia, where Roma are not native speakers of Croatian. Roma children, compared to the control group of respondents, achieve lower results on phonological awareness tasks that extend into when the children attend first grade (Dolean, Tincas \& Damsa, 2016).

It is to be expected that, due to insufficient knowledge of the Croatian language, Roma children perform worse on various language tasks (Cvikić \& Kuvač, 2007), which include phonological skills crucial for the acquisition of reading and writing. Research on the acquisition of reading and writing prerequisites by Roma children at the national level was conducted by Kovačić (2013): comparison of a small sample of Roma participants and a control group confirmed that Roma children obtain weaker results on tests made primarily for the Croatian language and are not ready for enrolment in first grade. In 2011, a Working Group for Monitoring and Controlling the Realisation of a Special Programme for Learning the Croatian Language for Students Belonging to the Roma National Minority was formed to implement the judgment of the European Court of Human Rights in the case Oršuš and others v. Croatia ${ }^{2}$. It analysed what teachers considered to be the biggest difficulties in acquiring the Croatian language, i.e. reading and writing. Among other things, they emphasised that Roma students do not acquire phoneme awareness even in later years of primary school and that they still cannot name all letters correctly.

Roma students are expected to enter the education system with nearly the same abilities and it is expected they will be able to follow the regular school curriculum with minimal individual adjustments. This group of students tries to "keep up with" their peers at the beginning of their formal education (Baucal, 2006), and difficulties in following education plan and programme can be detected. Given that Roma children come from an environment that is often both linguistically and culturally different, the 
obrazovanja, pri čemu usvojenost predvještina čitanja i pisanja ima značajnu ulogu.

\section{CILJ ISTRAŽIVANJA}

Cilj je ovoga rada ispitati razinu usvojenosti predvještina čitanja i pisanja kod djece - školskih obveznika romske nacionalne manjine te utvrditi razlikuju li se djeca koja su pripadnici romske nacionalne manjine $\mathrm{i}$ kontrolna skupina ispitanika u razvijenosti pojedinih sastavnica predvještina čitanja i pisanja.

Očekuje se da će rezultati ovoga istraživanja pridonijeti boljemu razumijevanju razvijenosti predvještina čitanja i pisanja na hrvatskome jeziku kod djece romske nacionalne manjine kao važnomu pokazatelju spremnosti za formalni početak usvajanja čitanja i pisanja tijekom nastavnoga procesa izvođenoga na njima nematerinskome hrvatskom jeziku.

\section{Hipoteze istraživanja}

Postavljene su sljedeće hipoteze istraživanja:

$\mathrm{H}_{1}$ : Rezultati djece Roma na ispitanim varijablama predvještina čitanja i pisanja odstupaju od urednoga postignuća.

$\mathrm{H}_{2}$ : Postoje statistički značajne razlike u razini razvijenosti predvještina čitanja i pisanja na hrvatskome jeziku između djece Roma i kontrolne skupine ispitanika.

\section{METODA}

\section{Uzorak}

Istraživanje je provedeno na prigodnome uzorku koji je uključivao 56 djece pripadnika romske nacionalne manjine (62,5\% dječaka, $\mathrm{M}=6$ god., $8 \mathrm{mj} ., \mathrm{SD}=0,46)$ i 55 djece pripadnika većinskoga stanovništva Republike Hrvatske (50,9 \% dječaka; $\mathrm{M}=6$ god., 8 mj., SD =0,48). U uzorak je uključena cjelokupna populacija školskih obveznika u školskoj godini 2019./20. koja po mjestu stanovanja pripada dvjema susjednim školama u Međimurskoj županiji. Kod šestero djece Roma uočena su veća jezična-govorna odstupanja koja nisu povezana s nerazumijevanjem hrvatskoga jezika. Tu se djecu dodatno usmjeravalo i poticalo. Svoj djeci Romima materinski je jezik bajaški need for a more detailed analysis of different aspects regarding their readiness to enter formal education system is needed, in which the acquisition of reading and writing prerequisites plays a significant role.

\section{AIM OF THE STUDY}

The aim of this study was to examine the level of reading and writing prerequisites in students belonging to the Roma national minority and to determine whether Roma children differ from a control group of participants in their level of development of reading and writing prerequisites.

It is expected that the results of the study will contribute to better understanding of the development of reading and writing prerequisites in Roma children, because they are the important indicator of readiness for the formal beginning of the acquisition of reading and writing during the teaching process conducted in their non-native Croatian language.

Research hypothesis

The following research hypotheses were formulated:

$\mathrm{H}_{1}$ : The results of Roma children on the examined variables of reading and writing prerequisites deviate from regular achievement.

$\mathrm{H}_{2}$ : There are statistically significant differences between Roma children and a control group of participants in the level of development of different components of reading and writing prerequisites in the Croatian language.

\section{METHOD}

\section{Sample}

The study was conducted on a sample comprising 56 children belonging to the Roma national minority ( $62.5 \%$ boys, $\mathrm{M}=6$ years, 8 months, $\mathrm{SD}=0.46$ ) and 55 children who are members of the majority population of the Republic of Croatia (50.9\% boys; $\mathrm{M}=6$ years, 8 months, $\mathrm{SD}=0.48$ ). The sample included the overall population of preschool children in the academic year 2019/20 who, based on their residence, belong to two neighbouring schools in Međimurje County. Increased speech and language difficulties were present in six Roma children, which were not connected to a lack of understanding of the Croatian 
rumunjski. Podskupini djece pripadnika većinskoga stanovništva u Republici Hrvatskoj pripada i troje djece $\mathrm{s}$ fonološko-artikulacijskim teškoćama, čije su se teškoće u području jezično-govorne produkcije uzele u obzir pri bodovanju pojedinih zadataka. Svoj djeci iz toga poduzorka materinski je jezik hrvatski te su svi jednojezični govornici.

\section{INSTRUMENT}

Za potrebe istraživanja korišteni su odabrani zadaci iz Testa za procjenu predvještina čitanja i pisanja (PredČiP test, Kuvač Kraljević i Lenček, 2012). PredČiP test standardizirani je test za procjenu predvještina nužnih za uspješno ovladavanje vještinama čitanja i pisanja na hrvatskome jeziku. Test je namijenjen djeci predškolske dobi, a koristi se kao trijažni test spremnosti djeteta za polazak u školu. Iako je standardiziran za hrvatski jezik, može se primjenjivati i na romsku populaciju. ${ }^{3}$ Sastoji se od 15 zadataka kojima se ispituje fonologija, odnosno fonološka obrada (fonološko imenovanje, brzo imenovanje i fonološka svjesnost), fonološko pamćenje (ponavljanje lažnih riječi i rečenica), pragmatika (prepričavanje priče) i jezično nespecifične vještine vizualne percepcije (prepoznavanje i precrtavanje). U ovome istraživanju primijenjeno je 14 zadataka testa koji ujedno čine i 14 istoimenih varijabli istraživanja, a detaljan opis primijenjenih zadataka prikazan je u Tablici 1 .

\section{POSTUPAK}

Istraživanje je provedeno u osnovnim školama tijekom regularnoga testiranja djece - školskih obveznika za upis u 1. razred. Ispitivanje djece provodile su stručne suradnice logopedinje educirane za primjenu testa i u vrijeme testiranja zaposlene u školama u koje su djeca došla na testiranje. Za provedbu ispitivanja osigurani su mirni uvjeti, a ispitivanje svakoga djeteta trajalo je oko 30 minu-

3 "Test se smije primijeniti kod osoba koje nisu izvorni govornici hrvatskoga jezika, odnosno kojima je hrvatski jezik drugi jezik, ali se obrazuju ili su uključeni u sustave u kojima se provode planovi i programi predviđeni za hrvatske jednojezične govornike primjerice kod pripadnika romske nacionalne manjine." (Kuvač Kraljević i Lenček, 2012: 12)/ "The test may be applied to persons who are not native speakers of Croatian, or for whom Croatian is a second language, but are educated or included in systems in which plans and programmes are implemented for Croatian monolingual speakers, for example, members of the Roma national minority." (Kuvač Kraljević \& Lenček, 2012: 12) language. These children were additionally engaged and encouraged. The first language of all Roma children was Bayash Romani. The subsample of children, members of the majority population of the Republic of Croatia, included three children with phonological and articulation difficulties, and their speech and language production difficulties were also taken into consideration during scoring of particular tasks. The first language of all children belonging to the subsample was Croatian and they were all monolingual.

\section{INSTRUMENT}

Certain tasks from the Test for assessment of reading and writing prerequisites (PredČiP test, Kuvač Kraljević \& Lenček, 2012) were used for the purpose of this study. The PredČip test is a standardised test for assessing prerequisites needed for successful acquisition of reading and writing skills in the Croatian language. The test is intended for preschool children and is used as a screening test of a child's readiness to enter formal education. Although it is standardised for the Croatian language, it can also be applied to the Roma population ${ }^{3}$. It consists of 15 tasks used to examine phonology (phonological naming, rapid naming and phonological awareness), phonological memory (pseudoword and sentence repetition), pragmatics (narrative abilities) and linguistically non-specific visual perception skills (recognition and copying). In the present study, 14 tasks were used and they covered 14 research variables. A detailed description of the applied tasks is shown in Table 1.

\section{PROCEDURE}

Research was conducted in two primary schools in Međimurje County, during regular testing of preschool children for their enrolment into first grade of primary school. Testing of children was conducted by speech and language pathologists educated in test application and employed in the schools in which the testing was conducted. Quiet conditions were ensured, and testing of each child took approximately 30 minutes. All parents signed their consent for their child's or children's test results to be statistically analysed at the group level for research purposes, whilst ensuring complete anonymity. 
Valentina Martan, Ivana Srebačić: Spremnost za ovladavanje vještinama čitanja i pisanja na hrvatskome jeziku kod djece romske nacionalne...

Tablica 1. Opis zadataka iz PredČiP testa primijenjenih u ovom istraživanju /Table 1. Description of the tasks from the Pred ČiP test applied in this research

\begin{tabular}{|c|c|c|c|}
\hline Assessment area & Task & Mode of assessment & Scoring method \\
\hline PHONOLOGY & rapid naming & $\begin{array}{l}\text { name } 20 \text { pictures whose } \\
\text { names are short and familiar } \\
\text { words }\end{array}$ & $\begin{array}{l}\text { time scoring in seconds (each unnamed } \\
\text { or incorrectly named image is scored } \\
\text { with an additional } 5 \text { seconds) }\end{array}$ \\
\hline $\begin{array}{l}\text { PHONOLOGICAL } \\
\text { AWARENESS }\end{array}$ & rhyme recognition & $\begin{array}{l}\text { among the given pairs of } \\
\text { words determine the pairs that } \\
\text { rhyme }\end{array}$ & score scale from 0 to 7 \\
\hline $\begin{array}{l}\text { PHONOLOGICAL } \\
\text { AWARENESS }\end{array}$ & rhyme production & $\begin{array}{l}\text { produce a word that rhymes } \\
\text { with the default word }\end{array}$ & score scale from 0 to 7 \\
\hline $\begin{array}{l}\text { PHONOLOGICAL } \\
\text { AWARENESS } \\
\end{array}$ & $\begin{array}{l}\text { segmenting } \\
\text { sentences into words }\end{array}$ & $\begin{array}{l}\text { count the words in the given } \\
\text { sentences }\end{array}$ & score scale from 0 to 7 \\
\hline $\begin{array}{l}\text { PHONOLOGICAL } \\
\text { AWARENESS }\end{array}$ & $\begin{array}{l}\text { syllable } \\
\text { segmentation }\end{array}$ & $\begin{array}{l}\text { break down words into } \\
\text { syllables }\end{array}$ & score scale from 0 to 7 \\
\hline $\begin{array}{l}\text { PHONOLOGICAL } \\
\text { AWARENESS }\end{array}$ & syllable blending & blend syllables into a word & score scale from 0 to 7 \\
\hline $\begin{array}{l}\text { PHONOLOGICAL } \\
\text { AWARENESS }\end{array}$ & $\begin{array}{l}\text { phonemic } \\
\text { segmentation }\end{array}$ & $\begin{array}{l}\text { break down words into } \\
\text { phonemes }\end{array}$ & score scale from 0 to 7 \\
\hline $\begin{array}{l}\text { PHONOLOGICAL } \\
\text { AWARENESS }\end{array}$ & phonemic blending & blend phonemes into words & score scale from 0 to 7 \\
\hline $\begin{array}{l}\text { PHONOLOGICAL } \\
\text { MEMORY AND SPEECH } \\
\text { LANGUAGE PROCESSING }\end{array}$ & $\begin{array}{l}\text { pseudoword } \\
\text { repetition }\end{array}$ & $\begin{array}{l}\text { repeat the given pseudowords } \\
\text { correctly }\end{array}$ & score scale from 0 to 7 \\
\hline $\begin{array}{l}\text { PHONOLOGICAL } \\
\text { MEMORY AND SPEECH } \\
\text { LANGUAGE PROCESSING }\end{array}$ & sentence repetition & $\begin{array}{l}\text { repeat the given sentences } \\
\text { correctly }\end{array}$ & score scale from 0 to 7 \\
\hline PHONOLOGICAL NAMING & $\begin{array}{l}\text { naming uppercase } \\
\text { letters }\end{array}$ & $\begin{array}{l}\text { name the uppercase letters on } \\
\text { the template }\end{array}$ & score scale from 0 to 30 \\
\hline PHONOLOGICAL NAMING & $\begin{array}{l}\text { naming lowercase } \\
\text { letters }\end{array}$ & $\begin{array}{l}\text { name the lowercase letters on } \\
\text { the template }\end{array}$ & score scale from 0 to 30 \\
\hline VISUAL PERCEPTION & recognition & $\begin{array}{l}\text { among four visually similar } \\
\text { samples, circle the one that is } \\
\text { identical to the given pattern }\end{array}$ & score scale from 0 to 10 \\
\hline VISUAL PERCEPTION & copying & $\begin{array}{l}\text { draw five characters according } \\
\text { to the template }\end{array}$ & $\begin{array}{l}\text { score scale from } 0 \text { to } 30 \\
\text { (four elements are scored: spatial } \\
\text { placement of the figure, derivation of } \\
\text { lines, closure of lines and detail) }\end{array}$ \\
\hline
\end{tabular}

ta. Ako djeca nisu razumjela uputu na hrvatskome jeziku, romski su im je pomagači preveli i objasnili. Roditelji sve djece potpisali su informirani pristanak za upotrebu rezultata testiranja njihova djeteta/njihove djece u istraživačke svrhe koji će se statistički analizirati isključivo na razini grupe, uz osiguranje potpune anonimnosti.

\section{METODE OBRADE PODATAKA}

Deskriptivnom statistikom opisani su osnovni statistički pokazatelji za uzorak, kao i za sve varijable za obje podskupine sudionika istraživanja. Kako bi se o dobivenim rezultatima moglo raspra-

\section{DATA ANALYSES}

Descriptive statistics were used to describe basic statistical indicators for the sample, as well as for all variables for both subgroups of research participants. In order to be able to discuss the obtained results in the context of the norms for the PredČip test (Kuvač Kraljević \& Lenček, 2012) ${ }^{4}$, the results of both groups of respondents on some variables were analysed in summary. Normality of distribution was tested using the Kolmogorov-Smirnov test. The Mann Whitney U test was used to test the differences between Roma children and the control 
viti i u kontekstu normi za PredČip test (Kuvač Kraljević i Lenček, 2012) ${ }^{4}$, rezultati obiju skupina ispitanika na nekim varijablama analizirani su sumarno. Normalnost distribucije ispitana je Kolmogorov-Smirnovljevim testom. Za utvrđivanje razlika u razini razvijenosti predvještina čitanja i pisanja između djece Roma i kontrolne skupine korišten je Mann-Whitney U test.

\section{REZULTATI I RASPRAVA}

Osnovni statistički pokazatelji za varijable predvještina čitanja i pisanja za obje podskupine sudionika istraživanja prikazani su u Tablici 2. Analiza prosječnih vrijednosti svih ispitanih varijabli predvještina čitanja i pisanja ukazuje na niže vrijednosti kod djece Roma. Budući da je provedeni test primarno jezični test, dobiveni rezultati svojevrstan su pokazatelj i ovladanosti hrvatskim jezikom. Rezultati su očekivani i ukazuju da su djeca Romi u nedovoljnoj mjeri spremna za učenje čitanja i pisanja na hrvatskome jeziku, što je sukladno i s nalazima drugih istraživanja provedenih u Hrvatskoj (Kovačić, 2013).

U nastavku slijedi analiza rezultata dobivenih na pojedinim zadacima testa. Tako je na zadacima brzoga imenovanja kojima se mjeri jezična tečnost i brzina kognitivne obrade (Lesaux i sur., 2008) djeci Romima potrebno znatno više vremena za imenovanje zadanih predmeta te je njihov rezultat u okviru lošega postignuća. Raspršenje rezultata za djecu Rome ukazuje na najveći varijabilitet odgovora upravo na toj varijabli. Iako se tijekom pripreme za zadatak zajedno s djecom imenovala svaka slika te iako se radi o relativno učestalim pojmovima, mnogi od njih imali su problema samostalno prizvati fonološke kodove, odnosno riječi za određeni predmet te su i nakon drugoga pokušaja imenovala na bajaškome jeziku. Kao što je već spomenuto, rječnik je hrvatskoga jezika djece Roma sužen (Cvikić i Kuvač, 2007), što je značajno utjecalo na njihov neuspjeh na ovome zadatku. Kod govornika koji nisu uravnoteženo dvojezični očekivano je da će rezultat na zadacima brzoga imenovanja na drugome jeziku biti lošiji od jednojezičnih govornika jer im je potreb-

4 Test za procjenjivanje predvještina čitanja i pisanja (PredČiP test) - priručnik, str. 54 / Test for assessing reading and writing prerequisites (predČiP test) - manual, p. 54 group in the level of development of reading and writing prerequisites.

\section{RESULTS AND DISCUSSION}

Basic statistical indicators for the variables of reading and writing prerequisites for both subgroups of participants are illustrated in Table 2. The analysis of average values for all examined variables of reading and writing prerequisites indicated lower values for Roma children. Since the conducted test is primarily a language test, the obtained results are a kind of indicator of mastery of the Croatian language. The results were as expected and indicated that Roma children were insufficiently prepared to learn to read and write in the Croatian language, which is in line with the findings of other research conducted in Croatia (Kovačić, 2013).

An analysis of the results obtained on individual test tasks follows. In rapid naming tasks, which measure language fluency and cognitive processing speed (Lesaux et al., 2008), Roma children needed significantly more time to name given subjects and their results were within poor achievement. The dispersion of results for Roma children indicated the greatest variability of responses on this variable. Although each image was named together with the children during the preparation for the task, and although the terms were relatively common, many children had problems recalling phonological codes, i.e. words for a certain subject, and named it after the second attempt in the Baja language. As already mentioned, the vocabulary of the Croatian language of Roma children is narrower (Cvikić \& Kuvač, 2007), which significantly influenced the performance of the children in the present task. For speakers who are not balanced bilinguals, it is expected that the results on rapid naming tasks in a second language will be worse than the results of monolingual speakers, because they need more time to recall a word from the mental lexicon (Schmidtke, 2014). It should be emphasised that the obtained results should be interpreted with caution because the prerequisite for solving this task is that children know how to name the listed subjects. Due to poorer vocabulary in the Croatian language, Roma children could not fully meet this criterion. 
no više vremena da prizovu riječ iz mentalnoga leksikona (Schmidtke, 2014). Valja naglasiti da je dobivene rezultate potrebno interpretirati s oprezom jer je preduvjet za rješavanje ovoga zadatka da djeca znaju imenovati navedene predmete. Zbog slabijega rječničkog znanja na hrvatskome jeziku djeca Romi nisu mogla u potpunosti zadovoljiti ovaj kriterij.

Među zadacima fonološke svjesnosti djeca Romi najniže prosječne rezultate postižu u proizvodnji rime, dok kontrolna skupina najniže prosječne rezultate iskazuje na zadacima fonemskoga stapanja. Razumijevanje i proizvodnja rime povezani su s kasnijim uspjehom u čitanju i pisanju (Dunst, Meter i Hamby, 2011; Snowling, 2000). Kod zadataka rime, čiji su ukupni rezultati djece Roma u okviru lošeg postignuća, ispitanici nisu razumjeli što se od njih traži unatoč pomoći govornika njihova jezika i uvježbavanju zadataka na dodatnim primjerima. Iako je rezultate potrebno interpretirati u kontekstu ispitivanja na nematerinskome jeziku, slabija osviještenost i nerazumijevanje pojma rime kod romske djece mogla bi se povezati i s nedovoljnom izloženosti pjesmicama i pričama u kontekstu obiteljskoga okruženja. Nedostatna izloženost materijalima za poticanje rane pismenosti u kućnome okruženju može biti povezana s otežanim razvojem vještina rane pismenosti (Kyuchukov, 2006). Na zadacima raščlambe rečenica na riječi djeca Romi postižu rezultate u okviru graničnoga postignuća. Ovim zadatkom pokazuje se sposobnost promišljanja u manjim jezičnim jedinicama, a za njegovo uspješno rješavanje potrebna je visoka razina fonološke i morfološke osviještenosti te leksička znanja koja su nužna za uočavanje i određivanje granice riječi, osobito u jezicima koji nemaju stalno mjesto naglaska kao što je hrvatski (Mandić, 2007). Najviše prosječne vrijednosti na mjerama fonološke svjesnosti kod obje skupine ispitanika postignute su na zadacima slogovnoga stapanja. Dobiveni rezultati potvrđuju da je slogovno stapanje najjednostavniji zadatak fonološke svjesnosti (Kuvač Kraljević i sur., 2019) te je za obje skupine bio lakši od slogovne raščlambe. Ipak, treba istaknuti da je ukupan uspjeh na zadacima slogovne svjesnosti kod obje skupine u okviru graničnoga postignuća. Sposobnost fonemske svjesnosti kod djece Roma,
Among phonological awareness tasks, Roma children achieved lower results in rhyme production tasks, while the control group achieved lowest results in phonemic blending tasks. Rhyme understanding and production are related to later success in reading and writing (Dunst, Meter \& Hamby, 2011; Snowling, 2000). In rhyming tasks, the overall result of Roma children is within poor achievement. They did not understand what they were supposed to do despite being provided with help from speakers of their language and practicing tasks on additional examples. Although the results need to be interpreted in the context of testing in a non-native language, weaker awareness and misunderstanding of the term "rhyme" in Roma children may reflect insufficient exposure to poems and stories for children in the family environment. Insufficient exposure to materials that encourage early literacy in the home environment may be associated with difficulties in developing early literacy skills (Kyuchukov, 2006). In segmenting sentences into words, Roma children achieved results within marginal achievement. This task demonstrates the ability to think in smaller language units, and its successful performance requires a high level of phonological and morphological awareness and lexical knowledge necessary to notice and determine the boundaries of words, especially in languages that do not have a permanent place of accent such as Croatian (Mandić, 2007). Highest average values on the measures of phonological awareness in both groups of respondents were achieved on the tasks of syllable blending. The obtained results confirm that syllable blending is the simplest task of phonological awareness (Kuvač Kraljević et al., 2019) and was easier for both groups than syllabic analysis. However, it should be noted that the overall success in the tasks of syllabic awareness in both groups is within the marginal achievement. Phonemic awareness among Roma children and the control group was within normal achievement in relation to the test norms. Roma children, on average, showed better results on phonemic blending tasks, which precede the skill of analysis (Ouellette \& Haley, 2011; Vancaš, 1999; according to Kuvač Kraljević \& Lenček, 2012). Phonemic awareness, as a reflection of deep phonological awareness, is an extremely important indicator of the future success of mastering reading and writing. A minimum 
ali i kod kontrolne skupine u odnosu na norme testa u okviru je urednoga postignuća. Djeca Romi u prosjeku bolje rezultate iskazuju na zadacima stapanja koji prethode vještini raščlambe (Ouellette i Haley, 2011, Vancaš, 1999; prema Kuvač Kraljević i Lenček, 2012). Fonemska svjesnost, kao odraz duboke fonološke osviještenosti, izuzetno je važan pokazatelj buduće uspješnosti ovladavanja čitanjem i pisanjem. Za usvajanje čitanja dovoljna je i minimalna razina fonemske osviještenosti, koja se kasnije razvija i usporedno sa sustavnom podukom čitanja (Olson, Wise, Johnson i Ring, 1997).

Mjere fonološkoga pamćenja i obrade govornoga jezika koje su ispitane kroz zadatke ponavljanja lažnih riječi i zadatke ponavljanja rečenica jednako tako ukazuju na loša postignuća djece Roma, dok su rezultati kontrolne skupine u okviru urednoga postignuća. Osobite teškoće uočene su u sposobnosti upamćivanja i ponavljanja rečenica, za čiju je izvedbu potrebno dobro poznavanje semantike i sintakse hrvatskoga jezika (Kuvač Kraljević i Lenček, 2012). Dvojezični govornici imaju mnogo kompleksnije obrasce neurološke aktivacije u zadacima radnoga pamćenja na drugom jeziku, stoga ne začuđuje podatak da im takvi zadaci mogu predstavljati veći izazov (Mägiste, 1984). Usprkos tome u zadatku ponavljanja lažnih riječi, koji je jezično manje specifičan, izjednačena je početna pozicija izvornih i neizvornih govornika hrvatskoga jezika. Upravo na tom zadatku djeca Romi postižu bolje rezultate u odnosu na zadatak ponavljanja rečenica, što je ohrabrujuće s obzirom na to da je ta fonološka vještina važna kod usvajanja novih riječi (Ardila, 2003; Kelić i sur., 2016).

$\mathrm{Na}$ zadacima imenovanja velikih i malih tiskanih slova djeca Romi postižu prosječne vrijednosti u okviru graničnoga postignuća. Djeca Romi u prosjeku poznaju tri puta manje velikih tiskanih slova i četiri puta manje malih tiskanih slova od kontrolne skupine. Rezultati su konzistentni s drugim nalazima na Romima - materinskim govornicima (LópezEscribano i Beltrán, 2009) te mogu biti posljedica činjenice da su djeca Romi u kućnome okruženju u manjoj mjeri izlagana pisanome materijalu (slovnicama, slikovnicama, vježbenicama) te različitim aktivnostima i igrama koje uključuju upotrebu slova (Bradley, Corwyn, McAdoo i García Coll, 2001; Duncan, Brooks-Gunn i Klebanov, 1994). level of phonemic awareness, which later develops in parallel with systematic reading instruction, is sufficient for reading acquisition (Olson, Wise, Johnson \& Ring, 1997).

Phonological memory and speech language processing measures, which were examined via tasks of pseudoword and sentence repetition, also indicated lower average values in Roma children, while the results of the control groups were within the normal achievement. Particular difficulties were noticed in the ability to remember and repeat sentences, which requires good semantic and syntactic skills (Kuvač Kraljević \& Lenček, 2012). Bilingual speakers have much more complex patterns of neurological activation in working memory tasks in a second language, so it is not surprising that these tasks can be more challenging for them (Mägiste, 1984). Nevertheless, in the task of repeating pseudowords, which is less linguistically specific, the initial position of native and non-native speakers of the Croatian language was equal. On this task Roma children achieved better results than on the repeating sentences task, which can be encouraging because this phonological skill is important in the acquisition of new words (Ardila, 2003; Kelić et al., 2016).

In naming uppercase and lowercase letters, Roma children also achieved average values within marginal achievement. Compared to the control group, Roma children on average knew three times fewer uppercase letters and four times fewer lowercase letters. These results are consistent with other findings on Roma - native speakers (LópezEscribano \& Beltrán, 2009) and can be due to the fact that Roma children in the home environment are less exposed to written material (grammars, picture books, exercise books) and various activities and games that involve the use of letters (Bradley, Corwyn, McAdoo \& García Coll, 2001; Duncan, Brooks-Gunn \& Klebanov, 1994). It should be emphasised that due to the lack of a written form of Baja language, Roma children are not exposed to written material in their mother tongue. Since there is a connection between naming letters and their future decoding and writing (Vuk, Lenček \& Ivšac Pavliša, 2020; Verhoeven, 2000), these results emphasise the importance of systematic teaching of letter naming in the preschool period. 
Valentina Martan, Ivana Srebačić: Spremnost za ovladavanje vještinama čitanja i pisanja na hrvatskome jeziku kod djece romske nacionalne...

Tablica 2. Osnovni statistički pokazatelji za ispitivane varijable / Table 2. Basic statistical indicators for examined variables

\begin{tabular}{|c|c|c|c|c|c|c|}
\hline Variable & Group & $\mathbf{N}$ & Min & Max & $\mathbf{M}$ & SD \\
\hline \multirow[t]{2}{*}{ Rapid naming } & Roma & 51 & 16 & 100 & 39.84 & 21.290 \\
\hline & non-Roma & 55 & 14 & 47 & 23.95 & 6.881 \\
\hline \multirow[t]{2}{*}{ Rhyme recognition } & Roma & 56 & 0 & 7 & 1.25 & 2.574 \\
\hline & non-Roma & 55 & 0 & 7 & 5.93 & 1.942 \\
\hline \multirow[t]{2}{*}{ Rhyme production } & Roma & 56 & 0 & 6 & 0.32 & 1.208 \\
\hline & non-Roma & 55 & 0 & 7 & 4.71 & 2.088 \\
\hline \multirow[t]{2}{*}{ Rhyme (in total) } & Roma & 56 & 0 & 13 & 1.57 & 3.432 \\
\hline & non-Roma & 55 & 0 & 14 & 10.63 & 3.827 \\
\hline \multirow[t]{2}{*}{ Segmentation of sentences into words } & Roma & 56 & 0 & 6 & 2.89 & 2.246 \\
\hline & non-Roma & 55 & 0 & 7 & 4.38 & 1.616 \\
\hline \multirow[t]{2}{*}{ Syllable segmentation } & Roma & 56 & 0 & 7 & 4.21 & 2.302 \\
\hline & non-Roma & 55 & 0 & 7 & 5.20 & 1.820 \\
\hline \multirow[t]{2}{*}{ Syllable blending } & Roma & 56 & 0 & 7 & 6.27 & 1.507 \\
\hline & non-Roma & 55 & 3 & 7 & 6.51 & 0.767 \\
\hline \multirow[t]{2}{*}{ Syllable awareness (in total) } & Roma & 56 & 3 & 14 & 10.48 & 2.815 \\
\hline & non-Roma & 55 & 3 & 14 & 11.71 & 2.274 \\
\hline \multirow[t]{2}{*}{ Phonemic segmentation } & Roma & 56 & 0 & 7 & 1.11 & 1.875 \\
\hline & non-Roma & 55 & 0 & 7 & 4.15 & 2.972 \\
\hline \multirow[t]{2}{*}{ Phonemic blending } & Roma & 56 & 0 & 7 & 2.93 & 2.287 \\
\hline & non-Roma & 55 & 0 & 7 & 3.75 & 2.633 \\
\hline \multirow[t]{2}{*}{ Phonemic awareness (in total) } & Roma & 56 & 0 & 14 & 4.04 & 3.785 \\
\hline & non-Roma & 55 & 0 & 14 & 7.89 & 5.350 \\
\hline \multirow[t]{2}{*}{ Naming uppercase letters } & Roma & 56 & 0 & 29 & 7.34 & 9.148 \\
\hline & non-Roma & 55 & 0 & 30 & 24.69 & 7.729 \\
\hline \multirow[t]{2}{*}{ Naming lowercase letters } & Roma & 56 & 0 & 21 & 3.96 & 5.850 \\
\hline & non-Roma & 55 & 0 & 30 & 18.38 & 9.156 \\
\hline \multirow[t]{2}{*}{ Naming (in total) } & Roma & 56 & 0 & 50 & 11.30 & 14.876 \\
\hline & non-Roma & 55 & 0 & 60 & 43.07 & 16.385 \\
\hline \multirow[t]{2}{*}{ Pseudoword repetition } & Roma & 56 & 0 & 7 & 4.77 & 1.748 \\
\hline & non-Roma & 55 & 3 & 7 & 5.87 & 1.218 \\
\hline \multirow[t]{2}{*}{ Sentence repetition } & Roma & 56 & 0 & 7 & 1.84 & 1.372 \\
\hline & non-Roma & 55 & 1 & 7 & 4.58 & 1.739 \\
\hline \multirow[t]{2}{*}{ Repetition (in total) } & Roma & 56 & 0 & 13 & 6.61 & 2.728 \\
\hline & non-Roma & 55 & 4 & 14 & 10.46 & 1.739 \\
\hline \multirow[t]{2}{*}{ Recognition } & Roma & 56 & 0 & 10 & 4.34 & 2.234 \\
\hline & non-Roma & 55 & 4 & 10 & 8.80 & 1.568 \\
\hline \multirow[t]{2}{*}{ Copying } & Roma & 56 & 0 & 19 & 9.46 & 5.576 \\
\hline & non-Roma & 55 & 9 & 18 & 14.89 & 2.543 \\
\hline
\end{tabular}

Roma $=$ children belonging to the Roma national minority; non-Roma = control group of participants; $\mathrm{N}=$ number of respondents; Min=lowest result, $\mathrm{Max}=$ maximum result; $\mathrm{M}=$ mean; $\mathrm{SD}=$ standard deviation

Treba naglasiti da zbog nedostatka pisma na bajaškome romskom djeca Romi ne mogu biti izloženi ni pisanome materijalu na materinskome jeziku. Budući da postoji povezanost između imenovanja slova i njihova budućeg dekodiranja i pisanja (Vuk, Lenček i Ivšac Pavliša, 2020; Verhoeven, 2000), ti
Roma children showed lower values and greater dispersion of answers on non-linguistic tasks of visual perception (recognition and copying), in which the initial position of native and non-native speakers was equal. Specific didactic tasks that encourage the development of visual skills in chil- 
Tablica 3. Rezultati Kolmogorov-Smirnovljeva testa normalnosti distribucije za ispitivane varijable/ Table 3. Results of the Kolmogorov-Smirnov test of the normality of distribution for examined variables

\begin{tabular}{|l|c|c|c|}
\hline Variable & $\mathbf{N}$ & $\mathbf{K}-\mathbf{S}$ & $\mathbf{p}$ \\
\hline Rapid naming & 111 & 2.716 & $.000^{* * *}$ \\
\hline Rhyme recognition & 111 & 3.946 & $.000^{* * *}$ \\
\hline Rhyme production & 111 & 4.412 & $.004 * *$ \\
\hline Segmenting sentences into words & 111 & 1.780 & .282 \\
\hline Syllable segmentation & 111 & 0.989 & .915 \\
\hline Syllable blending & 111 & 0.558 & $.000^{* * *}$ \\
\hline Phonemic segmentation & 111 & 2.600 & $.000^{* * *}$ \\
\hline Phonemic blending & 111 & 1.259 & .084 \\
\hline Naming uppercase letters & 111 & 3.658 & $.000^{* * *}$ \\
\hline Naming lowercase letters & 111 & 3.564 & $.000^{* * *}$ \\
\hline Pseudoword repetition & 111 & 1.548 & $.017^{*}$ \\
\hline Sentence repetition & 111 & 3.371 & $.000^{* * *}$ \\
\hline Recognition & 111 & 4.036 & $.000^{* * *}$ \\
\hline Copying & 111 & 2.911 & $.000^{* * *}$ \\
\hline
\end{tabular}

$\mathrm{N}=$ number of respondents; K-S=Kolmogorov Smirnov $\mathrm{z}$ value; ${ }^{*} \mathrm{p}<0.05 ;{ }^{* *} \mathrm{p}<0.01 ;{ }^{* * *} \mathrm{p}<0.001$

rezultati ističu važnost sustavne poduke imenovanja slova u predškolskome periodu.

Nadalje kod djece Roma uočene su niže vrijednosti te veće raspršenje odgovora i na nejezičnim zadacima vizualne percepcije (raspoznavanja i precrtavanja), u kojima je izjednačena početna pozicija izvornih i neizvornih govornika. Specifični didaktički zadaci koji potiču usvajanje vizualnih vještina kod djece u razdoblju od treće do šeste godine života imaju važnu ulogu u kasnijemu razvoju vještina čitanja i pisanja (Wildová i Kropáčková, 2015). Loše postignuće na zadacima vizualne percepcije, a posebno na zadacima precrtavanja, možemo sagledavati kroz prizmu nedostatna igranja s umetaljkama, slagalicama te općenito manjka igre, ali i kroz manjak iskustva sa sličnim zadacima tipa olovka - papir sve do polaska u predškolu. Istraživanja pokazuju da romska djeca posjeduju veoma malo didaktičkih igračaka i materijala, a prema izjavama njihovih roditelja njihova nabavka na dnu je liste prioriteta (Save the Children Annual Report, 2005).

Rezultati Kolmogorov-Smimovljeva testa ukazuju na to da većina varijabli statistički značajno odstupa od normalne distribucije (Tablica 3.) te su daljnje statističke analize provođene neparametrijskim testom za nezavisne uzorke (Mann-Whitney U test).

Utvrđeno je da postoje statistički značajne razlike između djece Roma i kontrolne skupine na većini varijabli koje ispituju predvještine čitanja i dren in the period from the third to the sixth year of life play an important role in the later development of reading and writing skills (Wildová \& Kropáčková, 2015). Lower results in visual perception tasks, especially in copying, can be viewed through the prism of the lack of play with shape sorters and puzzles and lack of play in general, as well as through the lack of experience with similar tasks on pen and paper until starting preschool. Studies have shown that these children own a very small amount of didactic toys and materials and, according to parents' statements, buying them is not a priority (Save the Children Annual Report, 2005).

Results of Kolmogorov-Smirnov test indicate that most variables significantly deviated from a normal distribution (Table 2). More detailed statistical analyses were conducted using a non-parametric test for independent samples (Mann Whitney U test).

It can be concluded that there are statistically significant differences between Roma children and the control group on most variables that assessed reading and writing prerequisites at the level of significance $<0.05$ (Table 4). Roma preschool children achieved significantly lower results than the control group on the variables rapid naming, rhyme recognition and production, segmenting sentences into words, syllable and phoneme segmentation, naming upper and lowercase letters, pseudoword and sentence repetition, as well as on variables of visual 
pisanja i to na razini značajnosti $<0,05$ (Tablica 4). Romska djeca - školski obveznici postigli su statistički značajno niže rezultate na varijablama brzoga imenovanja, raspoznavanja i proizvodnje rime, raščlambe rečenica na riječi, slogovne i fonemske raščlambe, imenovanja velikih i malih tiskanih slova, ponavljanja lažnih riječi i rečenica te na varijablama vizualne percepcije u odnosu na kontrolnu skupinu. Nisu utvrđene statistički značajne razlike na mjerama fonološke svjesnosti koje uključuju slogovno i fonemsko stapanje.

Dobivene razlike indikator su razlika u sposobnostima romske djece u ovladavanju predvještinama čitanja i pisanja na hrvatskome jeziku u odnosu na izvorne govornike, identificiranih u razdoblju pred polazak u školu, odnosno prije formalnoga početka usvajanja vještina čitanja i pisanja. No budući da je većina zadataka testa jezično specifična, možemo zaključiti da je nedovoljno poznavanje hrvatskoga jezika znatno utjecalo na rezultate ove djece $u$ ispitivanim predvještinama. Navedeni rezultati ukazuju na to da se razlike u razvijenosti važnih predvještina među djecom Romima i pripadnicima većinskoga stanovništva javljaju već u predškolskome periodu (López-Escribano i Beltrán, 2009). Nedovoljno razvijene jezične vještine, koje uključuju i predvještine čitanja i pisanja, najveća su prepreka uspješnoj inkluziji djece Roma u redovni obrazovni sustav (Babić, 2004; Kunac, Klasnić i Lalić, 2018). No s obzirom na to da su djeca Romi odgovarali na zadatke na jeziku koji im nije materinski, njihov je rezultat potrebno sagledati i s pozitivnoga aspekta. Svakako je ohrabrujući podatak da ne zaostaju za kontrolnom skupinom na zadacima slogovnoga i fonemskoga stapanja te da su u odnosu na norme testa njihova postignuća na zadacima fonemske svjesnosti u okviru urednoga postignuća, a u zadacima raščlambe rečenica, slogovne svjesnosti i fonološkoga imenovanja u okviru graničnoga postignuća. Stoga je s obzirom na dobivene rezultate postavljene hipoteze moguće tek djelomično prihvatiti.

Valja naglasiti da se, osim što ih povezuje odrastanje u istoj geografskoj regiji te približno ista kronološka dob, djeca Romi i kontrolna skupina u ovome istraživanju razlikuju po mnogo čimbenika koji imaju značajan utjecaj na dobivene razlike $\mathrm{u}$ rezultatima. Osim što nisu govornici hrvatskoga perception. Statistically significant differences were not obtained in phonological awareness measures that include syllable and phonemic blending.

The obtained results indicate a difference in the abilities of Roma children in mastering the reading and writing prerequisites in the Croatian language in relation to native speakers, identified in the period before starting school, i.e. before the formal start of acquiring reading and writing skills. However, since most of the test tasks are language-specific, we can conclude that insufficient knowledge of the Croatian language significantly affected the results of these children in the examined pre-skills. These results indicate that differences in the development of important pre-skills among Roma children and members of the majority population already appear in the preschool period (López-Escribano \& Beltrán, 2009). Insufficiently developed language skills, which include pre-reading and writing skills, are the largest obstacle to successful inclusion of Roma children in the regular education system (Babić, 2004; Kunac, Klasnić \& Lalić, 2018). However, given that Roma children in the present study responded to tasks in a non-native language, the results need to be viewed in a positive light. It is certainly encouraging that they did not lag behind the control group in the tasks of syllabic and phonemic blending and that in relation to the test norms their achievements were within the normal range on the tasks of phonemic awareness, and within the borderline range on the tasks of sentence analysis, syllabic awareness and phonological naming. Therefore, given the obtained results, the hypotheses can be only partially accepted.

It should be emphasised that except for growing up in the same geographical region and having approximately the same chronological age, the Roma children and the control group in the present study differed in many factors that had a significant impact on the differences in results. Apart from not being speakers of the Croatian language, as mentioned earlier, the Roma children were growing up in poverty, did not have sufficient cognitive stimulation with didactic materials, and family activities were not aimed at encouraging language skills in either the mother tongue or the second language. In addition, Roma children had attended preschool for only 10 months, whilst most children in the control group had attended from the age of three. It is important to 
Tablica 4. Rezultati Mann-Whitney U testa usporedbe rezultata djece romske nacionalne manjine i djece većinskoga stanovništva u RH na pojedinim varijablama predvještina čitanja i pisanja/ Table 4. Results of the Mann Whitney U test - Comparison of results of children belonging to the Roma national minority and children belonging to the majority population in the Republic of Croatia on specific variables of reading and writing prerequisites

\begin{tabular}{|c|c|c|c|c|c|c|}
\hline Variable & Group & $\mathbf{N}$ & M rang & $\mathbf{U}$ & $\mathbf{Z}$ & $\mathbf{P}$ \\
\hline \multirow[t]{2}{*}{ Rapid naming } & Roma & 56 & 73.05 & \multirow[t]{2}{*}{585.000} & \multirow[t]{2}{*}{-5.640} & \multirow[t]{2}{*}{$.000 * * *$} \\
\hline & non-Roma & 55 & 38.64 & & & \\
\hline \multirow[t]{2}{*}{ Rhyme recognition } & Roma & 56 & 34.97 & \multirow[t]{2}{*}{1958.500} & \multirow[t]{2}{*}{-7.455} & \multirow[t]{2}{*}{$.000 * * *$} \\
\hline & non-Roma & 55 & 77.41 & & & \\
\hline \multirow[t]{2}{*}{ Rhyme production } & Roma & 56 & 32.47 & \multirow[t]{2}{*}{1818.500} & \multirow[t]{2}{*}{-8.346} & \multirow[t]{2}{*}{$.000 * * *$} \\
\hline & non-Roma & 55 & 79.95 & & & \\
\hline \multirow{2}{*}{$\begin{array}{l}\text { Segmentation of sentences } \\
\text { into words }\end{array}$} & Roma & 56 & 46.13 & \multirow[t]{2}{*}{2583.500} & \multirow[t]{2}{*}{-3.306} & \multirow[t]{2}{*}{$.001 * *$} \\
\hline & non-Roma & 55 & 66.05 & & & \\
\hline \multirow[t]{2}{*}{ Syllable segmentation } & Roma & 56 & 49.57 & \multirow[t]{2}{*}{2776.000} & \multirow[t]{2}{*}{-2.163} & \multirow[t]{2}{*}{$.031 *$} \\
\hline & non-Roma & 55 & 62.55 & & & \\
\hline \multirow[t]{2}{*}{ Syllable blending } & Roma & 56 & 56.37 & \multirow[t]{2}{*}{3059.500} & \multirow[t]{2}{*}{-0.143} & \multirow[t]{2}{*}{.886} \\
\hline & non-Roma & 55 & 55.63 & & & \\
\hline \multirow[t]{2}{*}{ Phonemic segmentation } & Roma & 56 & 40.77 & \multirow[t]{2}{*}{2283.00} & \multirow[t]{2}{*}{-5.302} & \multirow[t]{2}{*}{$.000 * * *$} \\
\hline & non-Roma & 55 & 71.51 & & & \\
\hline \multirow[t]{2}{*}{ Phonemic blending } & Roma & 56 & 50.38 & \multirow[t]{2}{*}{2821.500} & \multirow[t]{2}{*}{-1.877} & .061 \\
\hline & non-Roma & 55 & 61.72 & & & \\
\hline Naming uppercase letters & Roma & 56 & 33.40 & 1870.500 & -7.503 & $.000 * * *$ \\
\hline & non-Roma & 55 & 79.01 & & & \\
\hline Naming lowercase letters & Roma & 56 & 35.57 & 1992.000 & -6.818 & $.000 * * *$ \\
\hline & non-Roma & 55 & 76.80 & & & \\
\hline Pseudoword repetition & Roma & 56 & 45.79 & 2564.000 & -3.469 & $.001 * *$ \\
\hline & non-Roma & 55 & 66.40 & & & \\
\hline Sentence repetition & Roma & 56 & 34.71 & 1944.000 & -7.135 & $.000 * * *$ \\
\hline & non-Roma & 55 & 77.67 & & & \\
\hline Recognition & Roma & 56 & 32.18 & 1802.000 & -7.975 & $.000 * *$ \\
\hline & non-Roma & 55 & 80.25 & & & \\
\hline Copying & Roma & 56 & 40.46 & 2265.500 & -5.149 & $.000 * * *$ \\
\hline & non-Roma & 55 & 71.83 & & & \\
\hline
\end{tabular}

Roma $=$ members of the Roma national minority; non-Roma $=$ control group of participants; $\mathrm{N}=$ number of respondents; Min $=$ minimum result, $\mathrm{Max}=$ maximum result; $\mathrm{M}_{\text {rang }}=$ measure for central tendency; ${ }^{*} \mathrm{p}<0.05 ; * * \mathrm{p}<0.01 ; * * * \mathrm{p}<0.001$

jezika, kao što smo prethodno napomenuli, djeca Romi odrastaju u siromaštvu, nemaju dovoljnu kognitivnu stimulaciju didaktičkim materijalima te obiteljske aktivnosti nisu usmjerene na poticanje jezičnih vještina ni na materinskome ni na drugome jeziku. Osim toga djeca Romi pohađaju predškolski program samo 10 mjeseci, a većina djece iz kontrolne skupine od treće godine. Važno je naglasiti da je potrebno u ranom periodu poticati oba jezika, pomoću materinskog jezika omogućiti usvajanje hrvatskoga jezika (Jelaska, 2007b), ali i sustavno poticati razvoj svih predvještina čitanja i pisanja. Primjena rezultata ovog testa može imati praktične implikacije te dati smjernice za kreiranje programa sustavnog emphasise that it is necessary to encourage both languages in the early period, to enable the acquisition of the Croatian language with the help of the mother tongue (Jelaska, 2007b), but also to systematically encourage the development of all reading and writing prerequisites. The application of the results of this test can have practical implications and provide guidelines for creating a program to systematically teach reading and writing prerequisites to Roma children through the preschool and early school period.

These results should be interpreted with caution due to several factors. Limitations of this study are reflected in the fact that the selected sample of participants was small and not representative. All the 
poučavanja predvještinama čitanja i pisanja djece Roma kroz predškolski i rani školski period.

Dobivene rezultate svakako je potrebno interpretirati s oprezom. Ograničenja ovoga istraživanja očituju se u tome da je odabrani uzorak sudionika nereprezentativan. Sva djeca Romi pripadaju istoj segregiranoj zajednici u kojoj su pohađala i predškolski program. Stoga se dobiveni rezultati ne mogu interpretirati uzimajući u obzir cjelokupnu populaciju Roma u Republici Hrvatskoj. Djeca iz kontrolne skupine nisu pohađala isti dječji vrtić kao i djeca Romi te stoga nisu bila izložena istim aktivnostima. Na kraju bismo kao glavni ograničavajući čimbenik istraživanja mogli izdvojiti činjenicu ispitivanja testom kojim se ispituju izvorni i neizvorni govornici te u kojemu je većina zadataka jezično specifična, no smatramo upotrebu testa opravdanom jer se ulaskom u obrazovni sustav na hrvatskome jeziku i od jednih i od drugih traže razvijene iste predvještine.

\section{ZAKLJUС̆AK}

Ovim istraživanjem nastojalo se pridonijeti boljemu razumijevanju spremnosti djece Roma za ovladavanje čitanjem i pisanjem na hrvatskome jeziku. Iz dobivenih rezultata vidljivo je da djeca Romi zaostaju za svojim vršnjacima izvornim govornicima na gotovo svim varijablama koje ispituju predvještine čitanja i pisanja. Djeca Romi zbog nedovoljna poznavanja hrvatskoga jezika, nepoticajnoga okruženja i života u siromaštvu spadaju u jednu od najranjivijih i najmarginaliziranijih skupina kojoj je potrebna sustavna i sveobuhvatna podrška od najranije dobi. Stoga je važno da im se omogući sustavno poticanje rane pismenosti na hrvatskome jeziku kroz visoko strukturirane programe usmjerene na sve ključne jezične i vizualno-perceptivne sastavnice, u čijemu kreiranju važnu ulogu imaju i stručni suradnici logopedi. Važnost ranoga otkrivanja odstupanja u području predvještina čitanja i pisanja putem standardiziranih testova i zadataka ključna je za planiranje učinkovita preventivnog djelovanja. U daljnjim istraživanjima trebalo bi dodatno empirijski istražiti razinu razvijenosti svih jezičnih sastavnica kod djece Roma na njihovu materinskom jeziku te njihov utjecaj na razinu usvojenosti (pred)vještina čitanja i pisanja, kao i ispitati utjecaj duljine i sadržajnih sastavnica predškolskoga programa na ovladanost predvještinama čitanja i pisanja na hrvatskome jeziku.
Roma children in the study belonged to the same segregated community in which they attended their preschool programme. Therefore, the obtained results cannot be generalised to the overall Roma population in the Republic of Croatia. Children from the control group did not attend the same kindergarten as Roma children, meaning that they were not exposed to the same activities within formal preschool education. Finally, as the main limiting factor of the research, we could single out the fact that we examined native and non-native speakers using a test in which most tasks are linguistically specific, but we consider that the use of the test is justified because entering the education system in the Croatian language requires development of the same pre-skills.

\section{CONCLUSION}

This study was intended to contribute to better understanding of the level of development of reading and writing prerequisites in Roma children and readiness for acquisition of reading and writing in the Croatian language. The obtained results clearly show that Roma children fall behind their peers in almost all variables used for assessing reading and writing prerequisites.

Roma children, due to insufficient knowledge of the Croatian language, an environment that does not encourage them, and life in poverty, belong to one of the most vulnerable and marginalised groups that needs systematic and comprehensive support from the earliest period of their lives. It is therefore important to enable all Roma children with systematic encouragement of early literacy in Croatian language through highly structured programmes directed towards all key linguistic and visual perceptual components. Professional speech and language pathologists play a significant role in the creation of such programmes. The importance of early detection of deviations in the area of reading and writing prerequisites via standardised tests and tasks is essential for planning efficient preventive activities. Further research should empirically study the level of development of all linguistic components in Roma children and their influence on the level of acquisition of reading and writing prerequisites and skills, as well as to examine the influence of the length and content of the preschool programme on the acquisition of reading and writing prerequisites in the Croatian language. 


\section{LITERATURA / REFERENCES}

Anthony, J. L. \& Francis, D. J. (2005). Development of Phonological Awareness. Current Directions in Psychological Science, 14(5), 255-259. DOI: 10.1111/j.0963-7214.2005.00376.x

Ardila, A. (2003). Language representation and working memory with bilinguals. Journal of communication disorders, 36(3), 233-240. DOI: 10.1016/S0021-9924(03)00022-4

Babić, D. (2004). Stigmatizacija i identitet Roma-pogled "izvana”: slučaj učenika Roma u naselju Kozari Bok. Migracijske i etničke teme, 20(4), 315-338.

Bagić, D., Burić, I., Dobrotić, I., Potočnik, D., Zrinščak, S. (2014). Romska svakodnevnica u Hrvatskoj: prepreke i mogućnosti za promjenu. Retrieved 2.5.2020. from https:/www.unicef.hr/wp-content/uploads/2015/09/undp-hrroma-everyday-2015.pdf

Baucal, A. (2006). Development of Mathematical and Language Literacy among Roma Students. Psihologija, 39(2), 207-227.

Biro, M., Smederevac, S., Tovilović, S. (2009). Ekonomski i kulturalni faktori školskog potignuća romske dece. Psihologija, 42(3), 273-288. DOI: 10.2298/PSI0903273B

Blaži, D., Buzdum, I., Kozarić-Cviković, M. (2011). Povezanost uspješnosti vještine čitanja s nekim aspektima fonološkog razvoja. Hrvatska revija za rehabilitacijska istraživanja, 47(2), 14-25.

Bracken, S. S. \& Fischel, J. E. (2008). Family Reading Behavior and Early Literacy Skills in Preschool Children from Low-Income Backgrounds. Early Education and Development, 19(1), 45-67. DOI: 10.1080/10409280701838835

Bradley, R. H., Corwyn, R. F., McAdoo, H. P., García Coll, C. (2001). The Home Environments of Children in the United States part I: Variations by Age, Ethnicity, and Poverty Status. Child Development, 72(6), 1844-1867. DOI: 10.1111/1467-8624.t01-1-00382

Caravolas, M. \& Landerl, K. (2010). The Influences of Syllable Structure and Reading Ability on the Development of Phoneme Awareness: A Longitudinal, Cross-Linguistic Study. Scientific Studies of Reading, 14(5), 464-484. DOI: $10.1080 / 10888430903034804$

Chan, L. L. \& Sylva, K. (2015). Exploring emergent literacy development in a second language: A selective literature review and conceptual framework for research. Journal of Early Childhood Literacy, 15(1), 3-36. DOI: $10.1177 / 2$ F 1468798414522824

Cvikić, L. \& Jelaska, Z. (2005). Istraživanja hrvatskoga kao drugoga i stranoga jezika. In Z. Jelaska (ed.), Hrvatski kao drugi i strani jezik (pp. 127-134). Zagreb: Hrvatska sveučilišna naklada.

Cvikić, L. \& Kuvač, J. (2007). Usvojenost hrvatskoga jezika u romske djece predškolske dobi. In L. Cvikić (ed.): Drugi jezik hrvatski: poučavanje hrvatskoga kao nematerinskoga jezika u predškoli i školi s posebnim osvrtom na poučavanje govornika bajaškoga romskoga: priručnik s radnim listovima (pp. 86 - 96). Zagreb: Profil International.

Dolean, D., Tincas, I., Damsa, C. I. (2016). Enhancing the Pre-literacy Skills of Roma Children: The Role of Socioeconomic Status and Classroom Interventions in the Development of Phonemic Awareness. New Educational Review, 45(3), 39-51. DOI: 10.15804/tner.2016.45.3.03

Dobravac, G., Cvikić, L., Kuvač Kraljević, J. (2011). Obavijesna vrijednost morfoloških i semantičkih ukazivača u određivanju vršitelja radnje u hrvatskome jeziku. Lahor: časopis za hrvatski kao materinski, drugi i strani jezik, 2(12), 135-149.

Duncan, G. J., Brooks-Gunn, J., Klebanov, P. K. (1994). Economic Deprivation and Early Childhood Development. Child Development, 65(2), 296-318. DOI: 10.1111/j.1467-8624.1994.tb00752.x

Dunst, C. J., Meter, D., Hamby, D. W. (2011). Relationship Between Young Children's Nursery Rhyme Experiences and Knowledge and Phonological and Print-Related Abilities. CELLReviews, 4(1), 1-12.

Erdos, C., Genesee, F., Savage, R., Haigh, C. A. (2011). Individual differences in second language reading outcomes. International Journal of Bilingualism, 15(1), 3-25. DOI: 10.1177/2F1367006910371022 
Valentina Martan, Ivana Srebačić: Spremnost za ovladavanje vještinama čitanja i pisanja na hrvatskome jeziku kod djece romske nacionalne...

Farah, M. J., Shera, D. M., Savage, J. H., Betancourt, L., Giannetta, J. M., Brodsky, N. L., Malmud, E. K., Hurt, H. (2006). Childhood Poverty: Specific Associations with Neurocognitive Development. Brain Research, 1110(1), 166-174. DOI: 10.1016/j.brainres.2006.06.072

Gathercole, S. E., Alloway, T. P., Willis, C., Adams, A. M. (2006). Working Memory in Children with Reading Disabilities. Journal of Experimental Child Psychology, 93(3), 265-281. DOI: 10.1016/j.jecp.2005.08.003

Grabe W. (2010). Reading in a Second Language. In R. B. Kaplan (ed.), The Oxford Handbook of Applied Linguistics (pp. 88-99). Oxford: Oxford University Press.

Hogan, T. P., Catts, H. W., Little, T. D. (2005). The Relationship Between Phonological Awareness and Reading. Language, Speech, and Hearing Services in Schools, 36(4), 285-293. DOI: 10.1044/0161-1461(2005/029)

Hrvatić, N. (2005). Obrazovanje Roma u Hrvatskoj: pretpostavka za bolju kvalitetu života? In M. Štambuk (ed.), Kako žive hrvatski Romi (pp. 177-200). Zagreb: Institut društvenih znanosti Ivo Pilar.

Ivšac Pavliša, J. \& Lenček, M. (2011). Fonološke vještine i fonološko pamćenje: neke razlike između djece urednoga jezičnoga razvoja. Hrvatska revija za rehabilitacijska istraživanja, 47(1), 1-16.

Jelaska, Z. et all (2005). Hrvatski kao drugi i strani jezik. Zagreb: Hrvatska sveučilišna naklada.

Jelaska, Z. (2007a). Ovladavanje jezikom: izvornojezična i inojezična istraživanja. Lahor: časopis za hrvatski kao materinski, drugi i strani jezik, 1(3), 86-99.

Jelaska, Z. (2007b). Dvojezičnost i višejezičnost. In L. Cvikić (ed.), Drugi jezik hrvatski: poučavanje hrvatskoga kao nematerinskoga jezika u predškoli i školi s posebnim osvrtom na poučavanje govornika bajaškoga romskoga: priručnik s radnim listovima (pp. 15-22). Zagreb: Profil International.

Kelić, M., Zelenika Zeba, M., Kuvač Kraljević, J. (2016). Što mjerimo pseudoriječima i kako mjerimo pseudoriječi. Logopedija, 6(2), 75-81. DOI: 10.31299/log.6.2.5

Kibby, M. Y., Marks, W., Morgan, S., Long, C. J. (2004). Specific Impairment in Developmental Reading Disabilities: A Working Memory Approach. Journal of Learning Disabilities, 37(4), 349-363. DOI: 10.1177/00222194040370040601

Kovačić, M. (2013). Ovladanost predvještinama čitanja i pisanja kod predškolske djece govornika romskog jezika. (Graduate thesis). Edukacijsko-rehabilitacijski fakultet Sveučilišta u Zagrebu, Zagreb.

Kunac, S., Klasnić, K., Lalić, S. (2018). Uključivanje Roma u hrvatsko društvo: istraživanje baznih podataka. Zagreb: Centar za mirovne studije.

Kutnjak Vrtarić, M. (2017). Magnet-škole kao mogući model obrazovne desegregacije i socijalnog uključivanja romske djece u Hrvatskoj. Školski vjesnik: časopis za pedagogijsku teoriju i praksu, 66(3), 423-442.

Kuvač Kraljević, J. \& Lenček, M. (2012). Test za procjenjivanje predvještina čitanja i pisanja (PredČiP test). Zagreb: Naklada Slap.

Kuvač Kraljević, J., Lenček, M., Matešić, K. (2019). Phonological Awareness and Letter Knowledge: Indicators of Early Literacy in Croatian. Croatian Journal of Education, 21(4), 1263-1293. DOI: 10.15516/cje.v21i4.3130

Kyuchukov, H. (2006). Early Home Literacy of Roma Children in Bulgaria. Education et Societes Plurilingues, 20, $51-62$.

Lervåg, A., Dolean, D., Tincas, I., Melby-Lervåg, M. (2019). Socioeconomic Background, Nonverbal IQ and School Absence Affects the Development of Vocabulary and Reading Comprehension in Children Living in Severe Poverty. Developmental Science, 22(5), 1-15. DOI: 10.1111/desc.12858

Lesaux, N. K., Geva, E., Koda, K., Siegel, L. S., Shanahan, T. (2008). Development of Literacy in Second-Language Learners. In D. August and T. Shanahan (eds.), Developing reading and writing in second-language learners. Lessons from the report of the National Reading Panel on language-minority children and youth (pp. 27 - 60). New York: Routledge. 
López-Escribano, C. i Beltrán, J. A. (2009). Early Predictors of Reading in Three Groups of Native Spanish Speakers: Spaniards, Gypsies, and Latin Americans. Spanish Journal of Psychology, 12(1), 84-95. DOI: 10.1017/ S1138741600001505

Mägiste E. (1984). Stroop tasks and dichotic translation: the development of interference patterns in bilinguals. Journal of Experimental Psychology: Learning, Memory, and Cognition, 10(2), 304-15. DOI: 10.1037/0278-7393.10.2.304

Mandić, D. (2007). Naglasak. Fluminensia: časopis za filološka istraživanja, 19(1), 77-94. Retrieved 20.9.2020. from https://hrcak.srce.hr/16734

Manis, F. R., Lindsey, K. A., Bailey, C. E. (2004). Development of Reading in Grades K-2 in Spanish-speaking English-language Learners. Learning Disabilities Research \& Practice, 19(4), 214-224. DOI: 10.1111/j.15405826.2004.00107.x

McLoyd, V. C. (1998). Socioeconomic Disadvantage and Child Development. American Psychologist, 53(2), 185-204. DOI: $10.1037 / / 0003-066 x .53 .2 .185$

Norton, E. S. \& Wolf, M. (2012). Rapid Automatized Naming (RAN) and Reading Fluency: Implications for Understanding and Treatment of Reading Disabilities. Annual Review of Psychology, 63, 427-452. DOI: 10.1146/ annurev-psych-120710-100431

Oller, K. D. \& Jarmulowicz, L. (2007). Language and literacy in bilingual children in the early school years. In E. Hoff and M. Shatz (eds.), Blackwell handbook of language development (pp. 368-386). Hoboken, New Jersey: Blackwell Publishing.

Olson, R. K., Wise, B. W., Johnson, M. C., Ring, J. (1997). The etiology and remediation of phonologically based word recognition and spelling disabilities. In B. A. Blachman (ed.), Foundations of reading acquisition and dyslexia: Implications for early intervention (pp. 305-326). Mahwah, NJ: Lawrence Erlbaum Associates, Inc.

Ouellette, G. P. \& Haley, A. (2011). One Complicated Extended Family: The Influence of Alphabetic Knowledge and Vocabulary on Phonemic Awareness. Journal of Research in Reading, 36(1), 1-13. DOI: 10.1111/j.14679817.2010.01486.x

Pahić, T., Vizek Vidović, V., Miljević-Riđički, R. (2011). Involvement of Roma Parents in Children's Education in Croatia: A Comparative Study. Journal of Research in International Education, 10(3), 275-292. DOI: $10.1177 / 1475240911422484$

Pravilnik o provođenju pripremne i dopunske nastave za učenike koji ne znaju ili nedostatno znaju hrvatski jezik i nastave materinskoga jezika i kulture države podrijetla učenika. Narodne novine, 15/13. Retrieved 10.4.2020. from www.nn.hr.

Radosavljević, P. (2009). Elementi utjecaja hrvatskog jezika na govor Bajaša u Belom Manastiru. Romanoslavica, $45,79-88$.

Radosavljević, P. (2016). Romi bajaši u Hrvatskoj. In T. Pišković and T. Vuković (eds.), Zbornik 44. seminara Zagrebačke slavističke škole: Drugi alteritet, identitet, kontakt u hrvatskome jeziku, književnosti i kulturi (pp. 185-195). Zagreb: Filozofski fakultet Sveučilišta u Zagrebu, Zagrebačka slavistička škola - Hrvatski seminar za strane slaviste.

Ramus, F. (2003). Developmental Dyslexia: Specific Phonological Deficit or General Sensorimotor Dysfunction? Current Opinion in Neurobiology, 13(2), 212-218. DOI: 10.1016/s0959-4388(03)00035-7

Reese L., Garnier H., Gallimore R., Goldenberg, C. (2000). Longitudinal analysis of the antecedents of emergent Spanish literacy and middle-school English reading achievement of Spanish-speaking students. American Educational Research Journal, 37(3), 633-662. DOI: 10.2307/1163484

Save the Children Annual Report. (2005). Retrieved 20.5.2020. from https://www.savethechildren.org/content/dam/ usa/reports/annual-report/annual-report/sc-2005-annualreport.pdf 
Scarborough, H. A. (2001). Connecting Early Language and Literacy to Later Reading (Dis)abilities: Evidence, Theory, and Practice. In S. Neuman and D. Dickinson (eds.), Handbook for research in early literacy (pp. 97-11). New York: Guilford Press.

Schmidtke, J. (2014). Second language experience modulates word retrieval effort in bilinguals: evidence from pupillometry. Frontiers in Psychology, 5(137), 1-16. DOI: 10.3389/fpsyg.2014.00137

Snowling, M. J. (2000). Dyslexia. Hoboken, New Jersey: Blackwell Publishing.

Turza-Bogdan, T. \& Cvikić, L. (2020). Lingusitic aspects of Roma minority education in Croatia: current state and perspectives. Danubius Noster, 1, 139-146.

Turza-Bogdan, T. \& Ciglar, V. (2011). Nastava hrvatskoga jezika u višejezičnoj sredini. In A. Bežen and B. Majhut (eds.), Redefiniranje tradicije: dječja književnost, suvremena komunikacija, jezici i dijete (pp. 271-282). Zagreb: Učiteljski fakultet Sveučilišta u Zagrebu

Turza-Bogdan, T., Cvikić, L., Svetec, M. (2007). Croatian as a Second Language - Faculty of Teacher Education Students' Views. Croatian Journal of Education, 19(Sp.Ed.No.1), 95-114. DOI: 10.15516/cje.v19i0.2385

Vuk, I., Lenček, M. \& Ivšac Pavliša, J. (2020). Početno pisanje slova u hrvatskom jeziku. Logopedija, 10 (1), 23-33. Retrieved 19.9.2020. from https://hrcak.srce.hr/243598

Verhoeven, L. (2000). Components in early second language reading and spelling. Scientific Studies of reading, 4(4), 313-330. DOI: 10.1207/S1532799XSSR0404 4

Wildova, R. \& Kropáčková, J. (2015). Early childhood pre-reading literacy development. Procedia-Social and Behavioral Sciences, 191, 878-883. DOI: 10.1016/j.sbspro.2015.04.418

Zorman, A. (2011). Problems in reading acquisition in a second or a foreign language. Metodički obzori: časopis za odgojno-obrazovnu teoriju i praksu, 6(11), 119-134. 